\title{
Is fatherhood allowed?: Media discourses of fatherhood in organizational life
}

Kangas, Emilia

2019-10

Kangas , E , Lämsä , A-M \& Jyrkinen , M 2019 , ' Is fatherhood allowed? Media discourses of fatherhood in organizational life ', Gender, Work and Organization , vol. 26 , no. 10 , pp. 1433-1450 . https://doi.org/10.1111/gwao.12352

http://hdl.handle.net/10138/326253

https://doi.org/10.1111/gwao.12352

unspecified

acceptedVersion

Downloaded from Helda, University of Helsinki institutional repository.

This is an electronic reprint of the original article.

This reprint may differ from the original in pagination and typographic detail.

Please cite the original version. 


\title{
Is Fatherhood Allowed? Media Discourses of Fatherhood in Organizational Life
}

Kangas, Emilia - Lämsä, Anna-Maija - Jyrkinen, Marjut. Is Fatherhood Allowed? Media Discourses of Fatherhood in Organizational Life. Gender, Work and Organization.

\begin{abstract}
It has been claimed that in the context of organizations and management, fathers are invisible. One source of tension for fathers who work and who want to participate in family life is that even though involved fatherhood is emerging in many Western societies, a family-oriented male identity is likely to be problematic for men in organizations. This article aims to contribute to a better understanding of a professional and managerial men's work-family relationship using discourse analysis on data from three different media sources in Finland, published during 1990-2015. We identified two competing discourses: one of stasis, the other of change. The stasis discourse is constructed around traditionally masculine management and fatherhood roles, while the changing discourse embodies more diverse masculinities and fatherhood. We conclude that although the discourse on fatherhood in the organizational context is moving towards gender equality, at the same time a strong discourse is putting a brake on such development, especially regarding management.
\end{abstract}

\section{Keywords}

gender, fatherhood, masculinity, leadership, organization, work-family relationship

\section{Introduction}

Fathers can be seen as ghosts - invisible bodies in the context of organizations. Although new forms of more participative fatherhood are emerging and are argued to be gradually gaining 
legitimacy in many Western societies (Dermott, 2008; Miller, 2011; Marsiglio and Roy, 2012; Kangas et al., 2017), organizations often tend to close their eyes and ears when the question of parenthood from the perspective of fathers is brought up (Burnett et al., 2013). A familyoriented male identity and behaviour are still understood as problematic, causing tensions for men in organizations (Hearn and Niemistö, 2012). Acker (2011) argues that although the ideal employee is typically presented in gender-neutral terms, the implicit assumptions and requirements of many jobs are that the employee is a man without worries and obligations outside of work. This unencumbered man is expected to focus only on work, be available for long working hours and to be unfettered by other responsibilities such as caring for children or sharing housework (ibid.). This ideal employee is compatible with traditional gender ideology, which reinforces the assumption that nurturing is the responsibility of the mother and not the father (Margsiglio, 2012). Although this understanding of the employee seems to be a good fit with the traditional idea of breadwinning fatherhood (Holter 2007; Gatrell 2007), its compatibility with more participative fatherhood has not yet really been established either in research or in practice. As Ranson (2012) claims, 'working fathers' have not yet been fully conceptualized. She argues that, even though the 'new father' involved with his children and engaged in hands-on care-giving already exists in the public discussion, it has not yet entirely replaced the concept of the man as the breadwinner.

Previous research has typically focused on how women can combine work and family (Ezzedeen and Ritchey, 2009; Özbilgin et al., 2011; Lämsä and Piilola, 2015; Heikkinen et al., 2014). In this study, we add to the literature by making the men's viewpoint visible. We argue that one crucial way to support both women's and men's opportunities to balance work and family life is for working men to participate in care at home more than they do now, with a more involved fatherhood (Liff and Cameron, 1997; Smithson and Stokoe, 2005). Involved fatherhood is a rather ambiguous concept, but usually it refers to a father who has a close and 
caring relationship with his children (Wall and Arnold, 2007). Risman (2009, p. 84) has insightfully stated that 'a just world would be one where sex category matters not at all beyond reproduction; economic and familial roles would be equally available to persons of any gender'.

In this article, we focus on the societal context of Finland and explore the discursive ways used by mass media to describe and represent the work-family relationship of men who are fathers as well as managers and professionals in organizational life. The mass media is a powerful and important force in the construction of social reality. The media build up and maintain meanings as well as influence people's thinking (Fairclough, 1998; McCullagh, 2002) about men's work-family relationship. This representation can have different implications for how men (as well as women and other genders) lead their lives.

In this study, the focus is on media discourses on managers and professionals as fathers, who are often role models in organizations (Weaver et al., 2005). We examine how the press portrays fatherhood in the organizational world, and how fathers as managers and professionals are described as behaving and are positioned by organizational discourses, cultures and policies. The voices in our analysis are those of journalists and the experts and practitioners they consult in order to find what is constructed to be happening in working life organizations. Managers especially men managers, are an important group to study, because assumptions and ideas in organizational life and management are still often masculine (Grint, 2011; Klenke 2011; Katila and Eriksson 2013; Powell, 2014). On the other hand, managers are in an influential position, which allows them to advance - or obstruct - new family-friendly organizational cultures.

Our study contributes to the discussion on changing masculinities in organizations (e.g. Collinson and Hearn, 2005; Holter, 2005; 2007; Burnett et al. 2013; Ladge et al. 2015). The contribution of this study is, firstly, in identifying how the general change 
towards involved fatherhood appeared in organizational life in Finland during 1990-2015, especially among men in professional and managerial positions. The second contribution lies in identifying possible managerial practices and masculine/ist ideals that obstruct this change. At the core of this research is, then, the collision between changes in fatherhood, the ideal of the unencumbered employee and masculine leadership.

The structure of our analysis is twofold. Firstly, we identified changes over recent decades in media texts on professional and managerial men's work-family relationship. Secondly, we considered whether the changes that we noted in the detected fatherhood discourses have the potential to challenge the ideal worker and/or masculine leadership ethos during this research period, or whether the discourses maintain the traditional ideas.

We explore the paradox in the Finnish societal context: Finland has relatively advanced gender policies, but fathers' readiness to use parental leave is lower than in other Nordic countries (Kela, 2017). Gender equality is seen as an important societal goal in Finland, which will make it possible to fully harness the expertise of both women and men for the general benefit of society (Katila and Eriksson, 2013). However, in practice, men still continue to have greater access to positions with power, social prestige, higher rewards and greater resources (The Global Gender Gap Report, 2017). Although women's participation in working life is high in Finland and most women work full-time (Statistics Finland, 2016), women still carry the main responsibility for housework and child care and have problems in career advancement.

Currently, parental leave is used almost exclusively by mothers in Finland; typically, men take only a few weeks of the statutory paternity leave. One-fifth of fathers do not use any of the available family leave (Kela, 2017). Furthermore, Närvi's (2018) study on men's parental leave in Finland reveals that it is very rare for organizations to arrange substitutes for men who take parental leave. Men's work tasks must therefore either be done 
by the men themselves before taking the leave or after they return to work, or then uncompleted tasks have to be distributed amongst colleagues, who might already be overburdened. Such practices hardly encourage men to take a very long parental leave. This builds up a difference between motherhood and fatherhood in organizational life: it is much rarer for organizations not to be prepared for maternity leave when a baby is born.

\section{Theoretical background}

Doing gender - doing fatherhood - or redoing it

We draw on the idea that gender is socially and historically constructed; it is not something people are, but rather, something people do, for example, through discursive practices at work, in families and in the wider society (West and Zimmerman, 1987; Billing, 2011). While doing gender, people reconstruct their gender roles, which are more or less learned. Thus, fatherhood is not just a biologically determined attribute but also the product of social actions located in a specific historical and social context (Marsiglio and Pleck, 2005, p. 259). Understanding gender as a dynamic, historically and actively constituted construction (Fenstermaker and West, 2002; West and Zimmerman, 2009; Martin, 2006) means that there is no one femininity or masculinity, but multiple patterns of masculinities and femininities co-exist (Connell, 2002). Consequently, various forms of fatherhood can exist and are constantly produced in various social processes (Poggio, 2006). According to the theory of doing gender, gender is done through social practices (West and Zimmerman 1987).

Although gender can be done in various ways, some discourses on gender tend to be more dominant than others. The dominant discourse can limit alternative ways to do gender, because to do gender is to engage in action in which the individual is accountable for "liv[ing] up to 
normative conceptions of femininity and masculinity' (Butler, 2004, p. 15). Fatherhood can be done in different ways, but some forms of fatherhood are more acceptable in particular social and historical contexts. However, undoing gender or redoing it is also possible (Billing, 2011). According to Butler, the gender binary can be destabilized and thereby undone (Butler, 1990, 2004), which affects the understanding and practices of parenthood. Although individuals can and do cross traditional gender lines, generally accepted and valued gender expectations, practices and norms restrict people's ability to do gender in a different way. Individuals are seldom truly undoing gender, but redoing it or doing it differently (see Kelan 2010; West and Zimmerman, 2009). Doing gender, as well as redoing it, takes place through discourses.

Holter (2005) argues that while inequalities work in complex and contradictory ways - sometimes also against men, individually and collectively - the overriding pattern of inequality works in favour of men and against women. Nevertheless, the effects of inequality are diverse and shifting. Often fathers' involvement in care takes place part time, as a secondary parent whose relationship with the children remains less important than that of the mother (Wall and Arnold, 2007). Previous studies of media representations of fatherhood indicate that men are typically represented as non-active subjects in the field of family care. Indeed, their voice concerning fatherhood is not often heard in the media; their doings are described by mothers or reporters, rather than fathers themselves (Sunderland, 2006).

\section{Masculinity in organizational life}

Traditionally, organizations have been built by and for men. The modern form of capitalism was a part of a historical process that created the masculinized public realm (Connell, 2002, p. 97-98). This traditional masculinity or 'masculine ethic' (Kanter, 1977, p. 43) consists of traits that are assumed to belong to men: 'a tough-minded approach to problems; analytical abilities 
to abstract and plan; a capacity to set aside personal, emotional consideration in the interests of task accomplishment; and a cognitive superiority in problem-solving and decision-making'. As Acker (2011, p. 67) puts it, even though an ideal employee is typically represented in gender-neutral terms in organizations, the assumptions and requirements of many jobs are that the worker is an unencumbered man without worries and obligations outside work.

Strong connections between management and masculinity are recognized in many critical management studies (Collinson and Hearn 2001). Masculinist discourses and practices are so dominant in business that anyone who pursues a managerial career must adopt them regardless of sex (Kerfoot and Knights 1998). According to Broadbridge and Hearn (2008), management is gendered in many ways. For example, managerial work is valued over work in the private domain. Furthermore, the assumptions and ideas of good leadership in organizational life are still masculine (Katila and Eriksson, 2013; Klenke, 2011; Powell, 2014). Despite this growing research interest in masculinities and leadership and the general equal opportunities rhetoric, it seems that masculine logic is still alive in management and leadership. Hearn argues (2014, p. 417) that organizations are still places of men's power and masculinities, although masculinity in organizational life and its management is no one single thing (ibid., p. 425). Masculinities do change, and there are various types and expressions of masculinity (Whitehead 2014). According to Whitehead (2014, 455), organizations remain located in a discursive arena which privileges men and/or ways of working which are harmfully masculinist, meaning that they demand of their subjects a commitment to practices that are neither collegial in approach nor individually empowering.

One way of viewing the privileged masculine world is to consider it through the concept of hegemonic masculinity. In previous studies, hegemonic masculinity has been conceptualized as well as criticized in many ways. In this research we follow Hearn and Morrell's (2012) definition of hegemonic masculinity as an ideal, a set of values that functions 
to include and exclude, and to organize society and organizations in gender unequal ways. Hegemonic masculinity embodies the most valued way of being a man, and it demands that all other men position themselves in relation to it (Connell and Messershmidt 2005). Connell and Messershmidt (2005) argue that even though hegemonic masculinity or masculinities may be constructed in ways that do not correspond to the lives of any actual men, hegemonic masculinities express widespread ideals, values and desires. However, such masculinities can be challenged. According to Hearn et al. (2012), critical analysis provides opportunities for new insights into men's practices and hegemonic masculinity/masculinities and offers possibilities for contesting inequality.

\section{Fatherhood in working life}

Collinson and Hearn (2005) have used the term 'distancing' to describe men's ways of freeing themselves from children and family responsibilities. Marsiglio and Roy(2012) note that men's involvement in work is seen to be the main cause of fathers' distance from their families. There are examples in earlier research (for example Hochschild, 1997) of the generally negative workplace responses to men's attempts to use parental leave or flexible work schedules. Various authors (Gatrell, 2007; Holter, 2007; Lewis et al., 2009) have found that fathers who try to reduce their working hours to be more involved with their children and families often face a poor response at work. According to Burnett et al. (2013), in organizational life familyoriented fathers are often marginalized, encountering gender disparity and negative peer relations. Allard et al. (2011) studied 377 father respondents in the private sector in Sweden and concluded that men feel that they receive little support, particularly from upper management, for combining work and family life. Holter (2007) claims that there is a deep gap between organizational practices and common attitudes to equality. Previous studies have 
presented notions such as involved fathering (Eräranta and Moisander, 2011; Wall and Arnold, 2007), new father(hood) (Barcley and Lupton, 1999), caring fathers (Johansson and Klinth, 2007) and intimate fatherhood (Dermott, 2008).

Halrynjo (2009) identified a typology of four different positions for fathers' adaptation to care and work responsibilities: the 'career' position, the 'care' position, the 'care and career' position and the 'patchwork career' position. Men who are positioned as 'career' men work long hours and have few childcare responsibilities, while those who are positioned as 'care' men have a lot of childcare responsibilities and reduced working hours. Men who are oriented towards 'care and career' work full-time, but also share parenthood responsibilities with their partners. The fourth group, men in the 'patchwork career' position, work in atypical employment, for example as freelancers, and they have very few or no childcare responsibilities. Halrynjo's study highlights the idea that 'career' men work in traditionally male-dominated sectors, such as technical and financial organizations with good or average career opportunities, where they are often in leading positions. These men say that they would like to work less but feel that it is impossible. The study alleged that the 'care and career' men, who are in the privileged position of both sharing parenting responsibilities and having a prosperous career, have difficulty in reconciling and meeting the demands of both spheres (ibid.).

Overall, it seems that appreciation of a more involved fatherhood is increasing in public discussions, and - albeit to some extent - in organizational practices in many Western societies (Dermott, 2008; Miller, 2011). However, the demands of the labour market do not fit well with the ideologies of caring fatherhood (Knijn and Selten 2002, p. 171). Fathers who incline towards a more involved fatherhood struggle to resolve the tension with colliding expectations from the traditional ideology of the ideal male worker (Brandth and Kvande, 2016; Halrynjo, 2009 Sallee, 2012). Ladge et al. (2015) found that despite the desire to be a 
more involved parent, the men in their study tended towards traditional views of fathering when they discussed their fatherhood in relation to their careers.

According to Marsiglio and Roy (2012, p. 3), both workplace culture and public policy have failed to support men in the new situation in which fathers are expected to have the role of both traditional breadwinner and involved father. Ladge et al. (2015) found that men expressed some ambiguity in their sense of fatherhood because of the conflicting views of traditional and involved fathering. Despite their claim that the 'organization man' is a concept of the past, reflecting outdated gender norms, this does not mean the end of the idea of masculine organizational practices, which still favour men who at least represent themselves as unencumbered and masculine professionals and managers.

\section{Methodology and analysis}

In this article, discourse is defined as a coherent system of meanings which is constructed in language use that brings the relevant topic into being (Phillips and Hardy, 2002). In our discourse analysis approach we apply the discursive theory of Jäger and Maier (2009), which is based on the idea that discourses are not only constructions of the social world but also serve particular ends; they exercise power in society and working life by institutionalizing, regulating and also enabling ways of talking, thinking and acting. Discourse also creates subject positions and defines subjectivities. A subject position is constructed when discourse is used to define and negotiate positions for the actors themselves and for others (Davies and Harre, 1990; Scheuer and Mills, 2016).

According to Hardy (2001), an essential part of the theory of discourse is the ongoing battle between the dominant discourse and one or many competing discourses. The dominant discourse has to reproduce and reformulate itself in interaction situations, day by 
day, to maintain its dominance (Hardy, 2001). Similarly, concepts such as father or manager exist in time and place. Currently, for example, a manager is constructed as a man who is strong, competitive and free from home responsibilities, but this representation can be challenged by competing discourses. Change is possible through marginalized discourses that become more visible and lead to alternative identities (Burr, 2015, p. 141).

Research material, method and analysis process

The discursive ways in which the media represent fatherhood can have an effect on the ideas and actions concerning men's work-family relationship that are valued in organizational life and society in general. Media representations not only reflect people's values and understandings, but also have a part in shaping and challenging these values and understandings. We examined the leading business magazines and the most widely read newspaper in Finland, all of which can be considered influential forces in reflecting and producing social reality, for example, how the work-family relationship is understood in the context of organizational life. The following media sources were analysed: 1) Helsingin Sanomat (HS), which is the biggest mainstream newspaper in Finland, 2) the business newspaper Kauppalehti (KL) and 3) the weekly financial and business magazine Talouselämä (TE).

These three sources reach a wide general audience and professional and business people throughout the country. HS regularly publishes articles on work and family issues. KL and TE are leading business publications, read mainly by professional people in business and other organizations. Data were collected systematically from issues of these three different media sources published during 1990-2015. This period was chosen because changes in the Finnish parental leave system, particularly more opportunities for fathers to participate in 
family life, were implemented then: in 1991, fathers were given the possibility of six days' paternity leave; in 2003, one month's paternity leave was introduced, which still today is the only non-transferable leave for fathers; and early in 2013, paternity leave and the father's quota were amalgamated, giving fathers the right to nine weeks' paternity leave.

The sample for this study was gathered through the publications' electronic databases (the HS archive, Talentum [which publishes TE] and the KL archive), using the keywords FATHER, FATHERHOOD, FAMILY, WORKLIFE and MANAGER. The search yielded 531 articles. All the articles were read through, and 67 articles were selected (see Table 1) where fatherhood was discussed from the viewpoint of male professionals and managers in the context of working life and organizations.

\section{'TABLE 1 HERE'}

In the data analysis, Willig's (2013) discourse analysis method was applied. First, we made notes about the various ways in which managerial and professional men's work-family relationship was discussed in the articles (ibid., p. 131). We then located the various constructions of the topic within wider contexts (ibid, p. 132), such as organizational and societal contexts. We also paid attention to any potential topics that were not addressed. For example, we noted the absence from the texts in the 1990s of any discussion of the role of organizations in supporting fathers' work-family balance. At this stage we held several rounds of discussion in our research group. We noticed that the selected texts contained two recurring ways of talking about and constructing men's work-family relationship: one around demands of work that were not reconcilable with involving fatherhood, and the other where involved fatherhood was constructed as a modern ideal that should be followed. The first discourse 
seemed to be thematically more coherent than the second, which had a wider variety of themes. We also noticed that the number of speakers in the texts expanded over time (see Table 2).

\section{'TABLE 2 HERE'}

During the period 1990-2009, the ratio of researchers and other experts, such as members of the Committee on Fatherhood (multisectoral high-level working group set up by the Ministry of Social Affair and Health), to other speakers was greater than in the later years, 2010-2015. In the later period, the proportion of male speakers increased, and the proportion of male managers' voices increased substantially.

As a result, two competing discourses became defined: one that sees no change and is stagnant, and the other that recognizes change taking place over time. The discourses were named 'Working fathers - no time for caring' and 'Fatherhood in flux'. Next, we examined more closely the action orientation in the texts. We asked what could possibly be achieved by constructing men's work-family relationship in this particular way in this particular discourse (Willig 2013, p. 132). We then took a closer look at the subject positions that the discourses offered by analysing how the man was positioned to other actors in the discourse. After this, we focused on the relationship between discourse and practice by considering the opportunities or constraints for action that the discourses could produce. In the final stage we concentrated on the subjectivities that the discourses created, focusing on the question of what could be felt or experienced from the man's position in the discourse (ibid. p.133). Overall, our analysis process was iterative, and the different phases overlapped each other. The results are summarized in Table 3.

'TABLE 3 here' 


\section{From stasis to change - two discourses}

\section{'Working fathers - no time for caring' discourse}

The first discourse was characterized by non-development, stagnation: it remained the same throughout the period of the study, from 1990 until 2015. In this discourse, organizations and working life in general are repeatedly constructed as places where the family is not highly valued. Working life appears to be hectic - there is no time for work-family issues. Managerial and professional work is constructed as incompatible with involved fatherhood. It is emphasized that the culture of work organizations forces professional and managerial men to give top priority to work obligations. The demands of work are described as leading to a situation where family obligations bend to the demands of work, not vice versa:

Most seriously, demanding work increasingly cuts middle-class men off from their families, Siltala claims. This includes middle managers, heads of department and specialists. Although people value their family above all else, the family has to give way to work. (TE 4.10.2002)

Men's work is constructed in a way which distances fathers from their families; it constructs the subject position of the distant father in relation to his children. Men report that they are absent from home both physically and mentally, and that home and care responsibilities rest with their spouses. Men are constructed as having no choice: they must adapt to the demands of working life and have no way of altering the situation. The discourse creates a subject 
position for the father as a victim, operating under the pressures and demands of an organizational culture that stresses the importance of work in men's lives. Men who are managers and professionals are represented as being unable to establish a good balance between work and family even if personally they would like to do so. In this sense, the man's experience of work-family balance is linked to powerlessness.

Overwork is described as a dominant practice in managerial and professional work - the norm, not the exception. Particularly fathers of young children are mentioned as working extra hours:

What is most surprising is that the fathers of young children do more overtime than other men. The motive isn't necessarily extra pay, because people don't always get paid for doing extra work-far from it. (HS 5.4.2002)

When a couple start a family, even couples who've shared domestic responsibilities equally before might fall back on traditional roles. The woman looks after the children and the home, and the man goes hunting for food. In the modern world, that means overtime. (HS 7.8.2012)

Men's fear of speaking out, taking parental leave or undertaking caring duties is constructed as being similar in the 1990s and in the 2010s, as the following quotations show:

'Rarely does anyone dare to stay at home to look after a sick child, let alone take parental leave,' says Jyri Lehtinen, father of three. (HS1.7.1995) 
'But I can fully understand young men who find it difficult to announce to the boss that they're going to take family leave. Men are under increasing pressure from their career and mothers from children,' says Kai Mykkänen from the Confederation of Finnish Industries. (KL 16.10.2014)

This discourse reinforces stereotypical ideas of the roles of mothers and fathers: it is assumed that women will look after the home and family and men will concentrate on work outside the home. Thus, in practice this discourse embodies traditional ideas about parenting and family responsibilities. Involved parenting is predominantly constructed as the mother's responsibility, while there is no mention at all of the idea of men's family obligations. Especially men who are managers are expected to appear not to have a family:

Successful managers are expected to behave as though they had no family at all. (HS 22.9.2013)

The discourse thus produces a representation of a male manager and professional who is entirely free of caring responsibilities. Altogether, this discourse institutionalizes traditional gender roles and strengthens the significance of traditional masculinity in organizational life, particularly in management.

\section{'Fatherhood in flux' discourse}

The 'fatherhood in flux' discourse constructs fatherhood as a gradually changing phenomenon, from distant fatherhood to involved fatherhood. During the study period, men's work-family relationship is represented as changing: the original dominant idea of 'breadwinner fatherhood' 
vanishes over the course of the years. By the end of the period, involved fatherhood has become a more possible alternative for professional and managerial men.

$1990 s$

In the first decade only a slight shift towards a more involved fatherhood, specifically among young male managers, can be detected in the texts. Young men are defined as first signifiers for (the emerging of) a more active and participatory fatherhood, while older male managers are defined as traditionalists who maintain the distant fatherhood model and hold back the development. In this decade researchers and other experts in the field were given a voice in the texts as authorities who defined the direction of fatherhood in society and working life:

Fortunately there seems to be some kind of positive rethinking of fatherhood. It's increasingly common for young fathers to take an equal share with the mother in looking after their children and their children's upbringing. To them fatherhood is an opportunity that they want to invest in. The problem for these fathers isn't lack of motivation or ignorance but the prejudices of working life and of others round about them. Even experts talk about the dangers of being soft. Is it any wonder if a man quietly slips into the old model of fatherhood? (HS 8.11.1998)

In the 1990s, paternity leave was not a major issue in the media, with one exception: the Prime Minister's paternity leave. This was constructed as an exceptional event, not only in the Finnish media but also in the international media - noticed enthusiastically in Finland. Even though the Prime Minister was not the first man in Finland to take a few weeks' paternity leave, he was certainly the most influential person to do so, positioned as he was as a role model for other fathers. In the discourse, he is constructed as an exemplary father and leader. Extensive media discussion of the Prime Minister's paternity leave appears as a significant discursive practice for change. Overall, in the 1990s, discussion about fatherhood in the organizational 
context was constructed as unusual, but not non-existent. The voices of fathers themselves were rarely heard in this decade, nor was there any discussion of the role and responsibilities of organizations as regards men's work-family relationship.

$2000 s$

The idea of involved fatherhood begins to emerge in the texts more in the 2000s. Political decision-makers, such as ministers, were mentioned as one group of actors promoting change. They are positioned as 'family men' in relation to other men in the media. These politicians openly introduce their family in the media articles and are presented as involved fathers:

'The family is most important to me.' If Wallin had more children, he would take the 18 days of paternity leave to which he's legally entitled, even after taking up his new ministerial appointment [for foreign affairs] in the New Year. Paavo Lipponen did that when he was Prime Minister - and the Spaniards gave him an equalities award for his progressiveness. (HS 18.6.2006)

However, this positive presentation of the politician as family man does not pass without criticism. While some media texts proclaim the idea of the family-man politician, they also question its authenticity, suspecting it may be linked to political ambition. However, although discussion around the representation of political decision-makers as family men is partly contradictory, it is a prominent discursive practice in the 2000s, positioning politicians as role models and supporting a more involved fatherhood for men. The men appear as actors who are continuing along the path shown by the Prime Minister in the previous decade. Young men from the professional and managerial world are also constructed as pioneers, emphasizing the importance of their work-family integration. One aspect of this discourse is men's talk about 
children's right to both parents: both men and women are represented as important parents, and equality between the spouses is underlined through the idea of shared parenting.

In the 2000 s, a generational stance towards change is expressed more clearly than in the previous decade. The texts underline the difference between old-time, traditional men and today's young men. Nevertheless, the change in fatherhood is also represented as being not entirely in the hands of fathers themselves: women are positioned as more important actors than men and more active subjects in promoting this ongoing change. The texts produce the idea that the change depends largely on wives' demands concerning who is going to take care of the family. Women's expectations are presented as what legitimates working fathers' increasing involvement in the family:

'Women's expectations of men have changed. The tired father who lounges on the sofa after work isn't looked on with much favour. You've got to have the washing-up brush in your hand or the baby under your arm,' jokes the 38-yearold marketing director of Kärkimedia, Jukka Kohonen. (TE 4.10.2002)

The demands for more involved fatherhood are presented as putting pressure on organizations to develop their practices concerning men's work and family integration. However, the change in organizational life is described not as being in organizations' interest, but instead, young fathers and their spouses are positioned as agents pushing for change. In other words, in the first decade of the 2000s, parents are constructed as active subjects, while organizations are positioned simply as adapting to changes going on in gender relations in families and society in general. Overall, the discussion has extended and become more polyphonic than in the previous decade. Voice in the texts is now given not only to researchers and experts in the field as well as politicians, but also, increasingly, to young fathers and their spouses. 
In the 2010s, attitudes towards involved fatherhood are already more widely discussed among parents and researchers, and fatherhood is beginning to be seen as something that concerns organizations. Change is described as starting to take place in organizations too. In 2014 one of the business magazines examined in this study (KL) even devoted a front-page article to the issue of fatherhood and a career. In the article, three male business professionals discuss their long parental leave and other experiences associated with their possibilities and aspirations to combine work and family. As in the previous decade, young men in particular are presented as a group who can rather freely balance work and family in the workplace. The discourse now gives organizations a more active role in the achieving of this balance: it is argued that an attitudinal change is happening, at least for young male professionals and managers in progressive organizations:

But times are changing. Satu Huber, the 50-year-old managing director of LähiTapiola, sees a clear difference between the generations. Men managers of her age or older prefer to leave their family in the background, but men who are younger than her often do an equal share of the housework, and they talk about it. (HS 22.9.2013)

In the 2010 s the media gives much more room than before to 'ordinary' fathers. While previously it was prominent politicians who were positioned as real role models in the texts, now business managers and professionals, typically younger men, are also positioned as good role models for fathers in the way they combine work and family. The relative number of 
managers amongst the speakers increased especially rapidly during this period. The men who appear in the texts as involved fathers are often very successful in their profession:

The men who gather in the children's playground in the park have got good jobs. They haven't stayed at home because they're unemployed. ... These well-paid trend-setting fathers are optimistic despite the figures. Idealists, they believe that a change is happening. It has to begin somewhere. Hopefully, the change will spread from around these swings, say the fathers. (HS 8.11.2015)

The successful professional and managerial men are constructed not only as more involved fathers but also as examples of a new ideal of management and leadership. As Hearn argues (2014), masculine leadership is not one thing - in this discourse successful professional and managerial men are described as creating new forms of masculine leadership by presenting possible connections between being involved in fatherhood and working in management. Additionally, organizations with family-friendly policies are just starting to emerge in the discourse. These organizations are constructed as forward-looking organizations that support a work-family balance for both genders. Many of their representatives describe how their organization emphasizes the development of an organizational culture that supports a better work-family relationship for employees. Supporting a work-family balance is mentioned as a factor for both employee well-being and productivity. These organizations are presented as sensitive pioneers in the new social trend of involved fatherhood. The work-family balance in particular is constructed as a competitive advantage for organizations. In sum, the support for involved fatherhood gets a broader base in the 2010s. It is not only young men and their spouses who are positioned in the media as agents of the change towards more involved fatherhood, but some progressive organizations also emerge in the discourse. 


\section{Discussion}

\section{Theoretical implications}

Taking the viewpoint of changing masculinities in organizational life (e.g. Collinson and Hearn, 2005; Holter, 2007; Burnett et al., 2013; Ladge et al., 2015), we participated in the discussion on the topic by investigating the work-family relationship of men who are managers and professionals and who are fathers, and conceptualized (cf. Ranson, 2012) the phenomenon in two ways. Firstly, it was shown that the Working fathers - no time for caring discourse privileges traditional masculinity (Holter 2007; Gatrell 2007; Whitehead 2014). Hence, in this discourse masculinity appears as hegemonic masculinity, which represents the most valued way of being a man (Connell and Messerschmidt, 2005) and simultaneously creates pressure on men to aspire to this ideal of masculinity. In line with several researchers (e.g. Lewis et al., 2009; Allard et al., 2011; Katila and Eriksson, 2013; Klenke, 2011; Burnett et al., 2013; Powell, 2014), we argue that this discourse reinforces and maintains the idea of traditional masculine ways of acting in organizations and limits men's opportunities to participate in family life and to have a good work-family balance in general.

Interestingly, men who are managers and professionals were constructed as victims in the Working fathers - no time for caring discourse. This is an exceptional way to build the identity of these men, because male managers in particular are usually represented as powerful actors in organizational life. This identity was constituted as given, and not really a man's own choice. One result of this can be that the discourse influences men to keep their family responsibilities invisible in organizations. On the other hand, it is worth critically consider the 'victimization' explanation, as managerial positions often imply power and self- 
determination at work. One could ponder how much of the work load is 'man-made' - for instance, long hours and work trips might even offer an escape from the hectic phase of everyday life when children are small. According to the 2017 survey Gender Equality Barometer in Finland, the majority of respondents were of the view that to refuse to work overtime is fairly easy for both mothers and fathers (Hokka, 2018).

Secondly, although the Working fathers - no time for caring discourse was dominant during the whole study period in the media texts, it was challenged (Hardy, 2001) by the discourse of Fatherhood in flux. This discourse emphasizes the possibility of re-doing gender (Billig, 2011; Kelan, 2010; West and Zimmerman, 2009) and the possibility for multiple patterns of masculinities (Connell, 2002; Hearn, 2014) in the work-family relationship. Moreover, the discourse challenges the idea(l) of hegemonic masculinity and endorses the view that masculinity is not one thing but is dynamic, adaptable, changing and always under reconstruction (Fenstermaker and West, 2002; Collinson and Hearn, 2005; Poggio, 2006; Kangas et al., 2017). In terms of men's work-family relationship, this discourse offers the potential for a more involved fatherhood in organizations and their management. We argue that the Fatherhood in flux discourse provides new insights into professional and managerial men's masculinities, and simultaneously can support equality between mothers and fathers in workfamily arrangements. When men are represented as involved fathers and equal parents, we are on the way towards more flexible gender roles. This second discourse indicates shifts in the normative constraints of masculinities and the potential for an emotionally adept man who can participate in care, as discussed by Cottingham (2017). Our results are compatible with Elliot's (2016) 'caring masculinities', which builds on masculine identities that emphasize affective, interdependent and emotional care by men. Thus, caring masculinity materialized through the involved fathering of managerial and professional men can be one way of shattering the hegemonic position of traditional masculinity in organizational life and its management. 


\section{Practical implications}

The traditional masculine way of doing gender in the Working fathers - no time for caring discourse reconstructs the double burden of working and care for women. Additionally, the unencumbered male (Acker, 2011) identity that is strong in this discourse distances men from children and family responsibilities (Collinson and Hearn, 2005). These also have a negative impact on women's participation in working life and career development - women are still in the minority in managerial positions in Finland (Katila and Eriksson, 2013; Global Gender Gap Report, 2017). This is reflected in the persistent gender pay gap in Finnish working life between women and men (17.4\% according to the European Commission, 2016); career breaks because of care responsibilities impact the lower pay rates as well as the retirement incomes of women compared to men.

The results of this study imply a strong need for restructuring family leaves towards increasing men's participation in care at home. One way to advance this kind of change is through legislation. Yet the much debated amendment of the family leave system in Finland failed in the political process in 2018. Although this study showed some change in the media texts concerning organizations' support of men's work-family balance, this is not a dominant way of speaking in the data. Rather, our findings support previous research results that organizations are still reconstructed as arenas that are dominated by traditional masculine values in relation to men's work-family integration (Halrynjo, 2009; Hearn, 2014), and they are not represented as being eager to advance men's opportunities to balance work and family (e.g. Gatrell, 2007; Holter, 2007; Lewis et al., 2009; Allard et al., 2011; Hearn and Niemistö, 2012; Burnett et al., 2013). Thus, it may take a long time before the detected discursive changes in the media texts become realized in organizational cultures, policies and practices, and finally 
do their part to increase gender equality in society. Therefore, as a practical implication of this study, we strongly suggest that during the next Finnish government period, current research results - as well as previous proposals by researchers, NGOs and labour unions - are taken as the basis for the preparation of the renewal of parental leave legislation, policies and practices. The contemporary parental leave system which emphasizes the responsibility of mothers for child care requires reconsideration to support men's care much more than now.

In addition to the renewal of legislation, similarly, interventions which promote men's opportunities to balance their work and family are necessary at the organizational level. Particularly needed are interventions by forward-looking organizations that encourage men to involve fatherhood in working life. It would be advantageous for good examples to be presented and discussed in public, i.e. the media. Especially in business contexts, where the economic aspects of organizational life are stressed, would it be crucial to show that a good work-family balance is advantageous to both employees and organizational outcomes; this could encourage the acceptance of involved fatherhood and a better work-family balance for men. Additionally, to advance organizations' role in promoting men's work-family relationship more intensively, change needs to be seen, particularly in the attitudes and practices of those in the most powerful positions in the organizations. Top management (often elderly men in Finland) can enable or restrain family-friendliness by formal and informal practices through their own example (Weaver, 2005). Older male managers are often the main gatekeepers for fathering or doing gender in organizations, and there might be also surprising change potential: many 'traditional' top managers have daughters, and the daughters' experiences of the work-family relationship may be a trigger for the managers to reconsider and reflect on their own attitudes and behaviour.

All in all, our results indicate that the change towards involved fatherhood is slow and requires role models in leaders and organizations as well as legislation and policy 
development. This supports Kvande's insights (2005), in which she proposes that the increased focus on paternity leave in the Nordic countries that has taken place during the last decades can be seen as a process of gendering and embodying men as fathers. In this study, the Fatherhood in flux discourse participates in societal level discussions, whereas the Working fathers - no time for caring discourse is more strongly an organizational discourse, which takes place mainly in working life and managerial contexts. Even though gendering men as fathers in the media discussions concerning the societal level seems to have more or less materialized during the studied period, it has only been slightly evidenced in organizational contexts. Seen from the practical point of view, then, the question is how long this dominance of traditional masculinity can limit alternative ways of doing gender and fatherhood in organizations while the pressure for change from society grows.

\section{Limitations and future research}

A limitation of our study is that the data set emphasises the binary of genders as women and men, and does not allow for analysis of other genders or non-heterosexual family settings. Thus in future research there is a need to analyse how, for instance, other groups of men than in this study and, for example, same-sex couples encounter the work-life interface and what kind of policy challenges emerge both at organizational and national levels.

The use of parental leaves by men depends on the sector - this seems to be easier in the public sector compared to the private sector (Hokka, 2018). This is an area where more research is needed, and for example, a qualitative analysis of specific features of different sectors, their leadership and organizational policies and cultures could reveal important aspects that affect men's and other groups' opportunities to integrate work and family and use parental leaves more than now. 
The construction of the two discourses in this study is one way of interpreting the phenomenon under investigation in the studied context. It needs to be stated that using media articles as research material is limited as it does not make men's actual experiences and organizations' practices visible. However, this study indicates that some change has taken place in the public media discussion of the topic in Finland during 1990-2015, with increasing attention being given to involved fatherhood (Holter, 2007; Johansson and Klinth, 2007; Eräranta and Moisander, 2011; Wall and Arnold 2007). Because the mass media is a powerful force in constructing our social reality (Fairclough, 1998; McCullagh, 2002), this gradual change has the potential to open up better opportunities for men to combine work and family and can advance gender equality in working life and the home sphere. For the future, we call for more research on both the empirical and theoretical levels. Studies that uncover organizational cultures and practices can offer valuable insights into men's work-family relationship and the various challenges that fathers obviously experience in organizational life. In addition, more theorizing is needed on the relations between the masculinities of management and the masculinities of fatherhood.

\section{Conclusion}

The results of this study show that in addition to progressive legislation on family leaves, involved fatherhood and a better work-family balance for men in professional and managerial positions requires supportive organizational cultures, and public and personal support from other men in managerial positions. Additionally, spousal support (Heikkinen and Lämsä, 2017) and shared experiences from progressive organizations are forces that can positively affect working life as well as the wider society. This emerging discourse that has opened the door to involved fatherhood in the media could continue to advance the reconstruction of social reality 
for equality in working life. Hopefully, more role models and examples of men who are not tied to traditional masculinity are given the floor in various discussions to enhance involved fatherhood.

To conclude, our answer to the question, 'Is fatherhood allowed in organizational life in the studied context?' is yes and no. Although traditional fatherhood was the dominant way of speaking of managerial and professional men's work-family relationship in the studied media texts, similarly, our findings support the idea that evidence of and ideas towards involved fatherhood were increasingly present in the texts during the 25 -year study period. Thus, it seems possible that this tendency will continue in the future.

TABLE 1. Media articles used.

\begin{tabular}{|l|r|r|r|r|}
\hline $\begin{array}{l}\text { Years } \\
\text { Media sources }\end{array}$ & 1990-1999 & 2000-2009 & 2010-2015 & Total \\
\hline $\begin{array}{l}\text { Kauppalehti } \\
\text { (KL) }\end{array}$ & 0 & 11 & 9 & 20 \\
\hline $\begin{array}{l}\text { Talouselämä } \\
(\mathrm{TE})\end{array}$ & 0 & 12 & 5 & 17 \\
\hline $\begin{array}{l}\text { Helsingin } \\
\text { Sanomat (HS) }\end{array}$ & 4 & 14 & 12 & 30 \\
\hline Total & 4 & 37 & 26 & 67 \\
\hline
\end{tabular}


TABLE 2. Identified speakers in articles.*

(*If an article included more than one speaker from the same category, they were counted only once. For example, if four fathers were quoted in the same article, it was calculated as one father speaker.)

\begin{tabular}{|l|r|r|r|}
\hline Years/Speakers & \multicolumn{2}{|l|}{$\begin{array}{l}\text { l000- } \\
\text { 1990-1999 }\end{array}$} & $2009-2015$ \\
\hline Manager (male) & & 8 & 12 \\
\hline Father & 1 & 23 & 21 \\
\hline Researcher/Expert & 3 & 18 & 8 \\
\hline Spouse (female) & & 6 & 1 \\
\hline Politician (male) & 1 & 3 & 2 \\
\hline Union representative & & 1 & 2 \\
\hline Manager (female) & & 1 & \\
\hline Politician (female) & & 1 & \\
\hline
\end{tabular}

TABLE 3. Summary of the results. 


\begin{tabular}{|c|c|c|c|c|}
\hline \multirow{2}{*}{$\begin{array}{l}\text { Discourses over } \\
\text { time }\end{array}$} & \multirow{2}{*}{$\begin{array}{l}\text { 'Working fathers - } \\
\text { no time for caring' } \\
\text { 1990-2015 }\end{array}$} & \multicolumn{3}{|c|}{ 'Fatherhood in flux' } \\
\hline & & 1990-1999 & 2000-2009 & $2010-2015$ \\
\hline $\begin{array}{l}\text { Action } \\
\text { orientation: } \\
\text { What is } \\
\text { achieved from } \\
\text { the discourse? }\end{array}$ & $\begin{array}{l}\text { Maintains the idea } \\
\text { that men's work is } \\
\text { incompatible with } \\
\text { fatherhood }\end{array}$ & $\begin{array}{l}\text { Shows that working } \\
\text { men can participate } \\
\text { in involved } \\
\text { fatherhood }\end{array}$ & $\begin{array}{l}\text { Highlights the idea of } \\
\text { sharing parenting } \\
\text { Demands that } \\
\text { organizations develop } \\
\text { their work-family } \\
\text { policies and practices } \\
\text { to pay attention to } \\
\text { men's viewpoint in } \\
\text { the work-family } \\
\text { balance }\end{array}$ & $\begin{array}{l}\text { Argues for the } \\
\text { advantages of involved } \\
\text { fatherhood for fathers } \\
\text { themselves and for } \\
\text { forward-looking } \\
\text { organizations }\end{array}$ \\
\hline $\begin{array}{l}\text { Subject } \\
\text { positions: How } \\
\text { is the man } \\
\text { positioned in } \\
\text { relation to other } \\
\text { actors in the } \\
\text { discourse? }\end{array}$ & $\begin{array}{l}\text { The man is a victim } \\
\text { of the organizational } \\
\text { culture, which } \\
\text { ignores the work- } \\
\text { family balance. } \\
\text { The man is a distant } \\
\text { father to his } \\
\text { children. } \\
\text { The man is not } \\
\text { responsible for the } \\
\text { home - this is his } \\
\text { spouse's (wife's) } \\
\text { responsibility. }\end{array}$ & $\begin{array}{l}\text { Young men are } \\
\text { signifiers of } \\
\text { involved fatherhood } \\
\text { before older male } \\
\text { managers in } \\
\text { organizations take it } \\
\text { up. } \\
\text { A famous male } \\
\text { politician (the } \\
\text { Prime Minister) } \\
\text { sets an example of } \\
\text { involved fatherhood } \\
\text { for other men in } \\
\text { society. }\end{array}$ & $\begin{array}{l}\text { Young men are trail- } \\
\text { blazers in } \\
\text { organizations in } \\
\text { combining work and } \\
\text { family. They do it } \\
\text { sooner than other } \\
\text { men in organizational } \\
\text { life. } \\
\text { Visible politicians are } \\
\text { examples of family } \\
\text { men more often than } \\
\text { other men in society. } \\
\text { Women are more } \\
\text { active agents than } \\
\text { men in promoting } \\
\text { involved fatherhood. }\end{array}$ & $\begin{array}{l}\text { Successful young } \\
\text { working men are role } \\
\text { models for combining } \\
\text { work and family in } \\
\text { practice sooner than } \\
\text { other men in } \\
\text { organizations. } \\
\text { Forward-looking } \\
\text { organizations promote } \\
\text { men's work-family } \\
\text { integration more than do } \\
\text { other organizations. } \\
\text { Young successful men } \\
\text { share parental } \\
\text { responsibilities with their } \\
\text { spouses (wives). }\end{array}$ \\
\hline $\begin{array}{l}\text { Discourse and } \\
\text { practice: What } \\
\text { kind of } \\
\text { opportunities or } \\
\text { constraints for } \\
\text { action does the } \\
\text { discourse } \\
\text { produce? }\end{array}$ & $\begin{array}{l}\text { Produces traditional } \\
\text { gender roles in } \\
\text { organizational life } \\
\text { that silence men's } \\
\text { family concerns and } \\
\text { responsibilities }\end{array}$ & $\begin{array}{l}\text { Produces } \\
\text { exceptions to } \\
\text { traditional gender } \\
\text { roles in society and } \\
\text { opens a door to } \\
\text { public discussion of } \\
\text { men's work-family } \\
\text { issues }\end{array}$ & $\begin{array}{l}\text { Produces the idea of } \\
\text { sharing parenting and } \\
\text { increases the } \\
\text { opportunity for men } \\
\text { to have a work- } \\
\text { family balance, but } \\
\text { this is demanded by } \\
\text { women }\end{array}$ & $\begin{array}{l}\text { Produces acceptance of } \\
\text { shared parenting in } \\
\text { forward-looking } \\
\text { organizations and } \\
\text { strengthens men's } \\
\text { aspirations to and } \\
\text { possibilities for involved } \\
\text { fatherhood }\end{array}$ \\
\hline $\begin{array}{l}\text { Subjectivities: } \\
\text { What is felt and } \\
\text { experienced } \\
\text { from within the } \\
\text { man's position? }\end{array}$ & $\begin{array}{l}\text { Men feel a sense of } \\
\text { powerlessness in } \\
\text { work-family issues. }\end{array}$ & $\begin{array}{l}\text { Involved } \\
\text { fatherhood is an } \\
\text { encouraging } \\
\text { possibility for some } \\
\text { men; involved } \\
\text { fatherhood is } \\
\text { resisted by older } \\
\text { male managers. }\end{array}$ & $\begin{array}{l}\text { Young men come to } \\
\text { participate in shared } \\
\text { parenting, pushed by } \\
\text { women. }\end{array}$ & $\begin{array}{l}\text { Young men feel that they } \\
\text { are good fathers when } \\
\text { they decide to be and are } \\
\text { able to dedicate } \\
\text { themselves to their } \\
\text { children. }\end{array}$ \\
\hline
\end{tabular}

\section{References}


Acker, J. (2011). Theorizing gender, race, and class in organizations. In: Jeanes, E. et al. (eds) Handbook of Gender, Work, and Organization, UK: John Wiley \& Sons, 65-80.

Allard, K., Haas, L. and Hwang, C.P. (2011). Family-supportive organizational culture and fathers' experiences of work-family conflict in Sweden. Gender, Work \& Organization, 18, 2, 141-157. doi:10.1111/j.1468-0432.2010.00540.x

Billing, Y.D. (2011). Are women in management victims of the phantom of the male norm? Gender, Work \& Organization, 18, 3, 298-317. doi: 10.1111/j.14680432.2010.00546.x

Barclay, L. and Lupton, D. (1999). The experiences of new fatherhood: a socio-cultural analysis. Journal of Advanced Nursing, 29, 4, 1013-1020.

Brandth, B. and Kvande, E. (2016). Fathers and flexible parental leave. Work, Employment and Society, 30, 2, 275-290.

Broadbridge, A. and Hearn, J. (2008). Gender and management: new directions in research and continuing patterns in practice. British Journal of Management 19, 1, 38-49.

Burnett, S.B., Gatrell, C. J., Cooper, C. and Sparrow, P. (2013). Fathers at work: A ghost in the organizational machine. Gender, Work \& Organization, 20, 6, 632-646. doi: 10.1111/gwao. 12000

Burr, V. (2015). Social Constructionism. London and New York: Routledge.

Butler, J. (1990). Gender Trouble. London: Routledge.

Butler, J. (2004). Undoing Gender. Psychology Press. New York: Routledge.

Cheung, F. M. and Halpern, D. F. (2010). Women at the top: Powerful leaders define success as work+ family in a culture of gender. American Psychologist, 65, 3, 182-193.

Collinson, D. L. and Hearn, J. (2001). Naming men as men: implications for work, organization and management. In Whitehead SM and Barret FJ. (eds) The Sociology of Masculinity, Polity Press. Cambridge, 144-169.

Collinson, D.L. and Hearn, J. (2005). Men and masculinities in work, organizations and management. In Kimmel M.S., Hearn J. and Connell R.W. (eds) Handbook of Studies on Men and Masculinities. London, New Dehli: Sage, 298-310.

Connell, R.W. (2002). Gender. Cambridge: Polity Press.

Connell, R. W. and Messerschmidt, J. W. (2005). Hegemonic masculinity: Rethinking the concept. Gender \& Society, 19, 6, 829-859.

Cottingham, M.D. (2017), Caring moments and their men: masculine emotion practice in nursing. NORMA: International Journal for Masculinity Studies, 12, 270-285.

Dermott, E. (2008). Intimate Fatherhood. A Sociological analysis. Oxon: Routledge. 
Elliot, K. (2016). Caring masculinities. Theorizing and emerging concept. Men and Masculinities 19, 3, 240-259.

Eräranta, K. and Moisander, J. (2011). Psychological regimes of truth and father identity: challenges for work/life integration. Organization Studies, 32, 4, 509-526.

European Commission (2016). The Gender Pay Gap in 2016, https://ec.europa.eu/eurostat/statisticsexplained/index.php/Gender_pay_gap_statistics (Accessed 2 November 2018).

Ezzedeen, S.R. and Ritchey, K.G. (2009). Career advancement and family balance strategies of executive women. Gender in Management: An International Journal 24, 6, 388-411.

Fairclough, N. (1998). Discourse and Social Change. Oxford: Polity Press.

Fenstermaker, S. and West, C. (2002). Doing Gender, Doing Difference: Inequality, Power, and Institutional Change. New York: Psychology Press.

Gatrell, C. (2007). Whose child is it anyway? The negotiation of paternal entitlements within marriage. The Sociological Review, 55, 2, 352-372.

Grint, K. (2011). A history of leadership. In Bryman A. et al. (eds) The SAGE handbook of leadership. 14, 1, London: Sage Publications Ltd, 3-14.

Greenhaus, J.H. and Powell, G.N. (2006). When work and family are allies: A theory of workfamily enrichment. Academy of Management Review, 31, 1, 72-92.

Halrynjo, S. (2009). Men's work-life conflict: career, care and self-realization: patterns of privileges and dilemmas. Gender, Work \& Organization, 16, 1, 98-125.

Hardy, C. (2001). Researching organizational discourse. International Studies of Management \& Organization, 31, 3, 25-47.

Hearn, J. (2014). Contextualizing men, masculinities, leadership and management: Gender/intersectionalities, local/transnational, embodied/virtual, theory/practice. In Kumra, S., Simpson, R., \& Burke, R. J. (eds) The Oxford Handbook of Gender in Organizations. Oxford: Oxford University Press, 417-437.

Hearn, J., and Morrell, R. (2012). Reviewing hegemonic masculinities and men in Sweden and South Africa. Men and Masculinities, 15, 1, 3-10.

Hearn, J. and Niemistö, C. (2012) Men, managers, fathers and home-work relations: National context, organisational policies, and individual lives. In MacDonald, P. and Jeanes E, (eds) Men, Wage Work and Family. London: Routledge, 2012, 1, 95113. 
Hearn, J., Nordberg, M., Andersson, K., Balkmar, D., Gottzén, L., Klinth, R., ... \& Sandberg, L. (2012). Hegemonic masculinity and beyond: 40 years of research in Sweden. Men and Masculinities, 15, 1, 31-55.

Heikkinen, S., Lämsä, A-M. (2017). Narratives of spousal support for the careers of men in managerial posts. Gender, Work and Organization, 24, 2, 171-193.

Heikkinen, S., Lämsä, A. M. and Hiillos, M. (2014). Narratives by women managers about spousal support for their careers. Scandinavian Journal of Management, 30, 1, 27-39.

Hochschild, A. R. (1997). The Time Bind: When work becomes home and home becomes work. New York: Metropolitan.

Hokka, P. (2018). Työn ja perheen yhteensovittaminen. Tasa-arvobarometri 2017, Sosiaali- ja terveysministeriön julkaisuja 8/2018, 81-95. http://urn.fi/URN:ISBN:978-95200-3932-5 (Accessed 9 November 2018).

Holter, O.G. (2005). Social theories for researching men and masculinities. In Kimmel MS, Hearn J, and Connell RW (eds) Handbook of Studies on Men and Masculinities. 15-34. London, New Dehli: Sage.

Holter, O.G. (2007) Men's work and family reconciliation in Europe. Men and Masculinities, $9,4,425-456$.

Johansson, T. and Klinth, R. (2007). Caring fathers: The ideology of gender equality and masculine positions. Men and Masculinities, 11, 42-62.

Jäger, S. and Maier, F. (2009). Theoretical and methodological aspects of Foucauldian critical discourse analysis and dispositive analysis. In Wodak R. and Meyer M (eds) Methods of critical discourse analysis. London: Sage. 34-61.

Kangas, E., Lämsä, A-M. and Heikkinen, S. (2017). Father managers (un)doing traditional masculinity. In Pilinska A. (eds) Fatherhood in Contemporary Discourse - Focus on Fathers. Oxford: Cambridge Scholars Publishing. 17-30.

Kanter, R. M. (1977). Men and Women of the Corporation (Vol. 5049). Hachette UK: Basic books.

Katila, S. and Eriksson, P. (2013). He is a firm, strong-minded and empowering leader, but is she? Gendered positioning of female and male CEOs. Gender, Work \& Organization, 20, 1, 71-84. doi: 10.1111/j.1468-0432.2011.00570.x

Kela (2017). The Social Insurance Institution of Finland. Available online at. http://www.kela.fi/perhevapaat-tietopaketti (Accessed 24 October 2017). 
Kelan, E. K. (2010). Gender logic and (un)doing gender at work. Gender, Work \& Organization, 17, 2, 174-194. doi: 10.1111/j.1468-0432.2009.00459.x

Kerfoot, D. and Knights, D. (1998). Managing masculinity in contemporary organizational life: A managerial project. Organization, 5, 1, 7-26.

Knijn, T. and Selten, P. (2002). Transformations of fatherhood: the Netherlands. In Hobson, B. (eds) Making Men into Fathers: Men. Masculinities and the Social Politics of Fatherhood. Cambridge: Cambridge University Press, 168-187.

Klenke, K. (2011). Women in Leadership: Contextual dynamics and boundaries. New York: Springer Publishing Company.

Kvande, E. (2005). Embodying male workers as fathers in a flexible working life. In Morgan, D., Brandth, B., \& Kvande, E. (eds) Gender, Bodies and Work. London: Ashgate, $75-88$.

Ladge, J. J., Humberd, B. K., Baskerville Watkins, M. and Harrington, B. (2015). Updating the organization MAN: An examination of involved fathering in the workplace. Academy of Management Perspectives, 29, 1, 152-171.

Lewis, S., Brannen, J. and Nilsen, A. (2009). Work, Families and Organisations in Transition. London: Policy Press.

Liff, S. and Cameron, I. (1997). Changing equality cultures to move beyond 'women's problems'. Gender, Work \& Organization, 4, 1, 35-46.

Lämsä, A-M. and Piilola, A. (2015). Women's Leadership in Finland: The Meaning of Motherhood as Related to Leadership for Women Managers. In Ngunjiri, F.W. \& Madsen, S.R. (eds) Women and Leadership Around the World. IAP.

Marsiglio, W. and Pleck, J. H. (2005). Fatherhood and masculinities. In Michael, S. et al. (eds) The Handbook of Studies on Men and Masculinities. Thousand Oaks, London, New Delhi: Sage Publications, 249-269.

Marsiglio, W. and Roy, K. (2012). Nurturing Dads. Social Initiatives for Contemporary Fatherhood. New York: Russell Sage Foundation. doi: 10.1111/j.14680432.2006.00307.x

McCullagh, C. (2002). Media Power. A Sociological Introduction. UK: Macmillan Education. Miller, T. (2011). Making Sense of Fatherhood: Gender, caring and work. Cambridge: University Press.

Närvi, J. (2018). Isä hoitaa vai hoitaako? Helsinki: Terveyden ja hyvinvoinnin laitos.

Phillips, N. and Hardy, C. (2002). Understanding Discourse Analysis. Thousand Oaks: Sage. 
Poggio, B. (2006). Editorial: Outline of a Theory of Gender Practices. Gender, Work \& Organization, 13, 3, 225-233.

Powell, G. N. (2014). Sex, Gender, and Leadership. In Kumra, S., Simpson, R. and Burke, R.J. (eds) The Oxford handbook of gender in organizations. New York: Oxford University Press.

Ranson, G. (2012). Men, paid employment and family responsibilities: Conceptualizing the 'working father'. Gender, Work \& Organization, 19, 6, 741-761.

Risman, B. J. (2009). From doing to undoing: Gender as we know it. Gender \& Society, 23, 1, 81-84.

Scheuer, C.L. and Mills, A. J. (2016). Discursivity and media constructions of the intern: Implications for pedagogy and practice. Academy of Management Learning \& Education, 15, 3, 456-470.

Smithson, J. and Stokoe, E. H. (2005). Discourses of work-life balance: Negotiating 'genderblind' terms in organizations. Gender Work \& Organization, 12, 2, 14768. doi: 10.1111/j.1468-0432.2005.00267.x

Sunderland, J. (2006). "Parenting" or "Mothering"? The case of modern childcare magazines. Discourse and Society, 17, 4, 503-2.

Statistics Finland. (2016). Naiset ja miehet Suomessa. Helsinki: Edita Publishing Oy.

Wall, G. and Arnold, S. (2007). How involved is involved fathering? An exploration of the contemporary culture of fatherhood. Gender \& Society, 21, 4, 508-527.

Weaver, G. R., Treviño, L. K., \& Agle, B. (2005). " Somebody I look up to:" Ethical role models in organizations. Organizational Dynamics, 34, 4, 313-330.

West, C. and Zimmerman, D. H. (1987). Doing Gender. Gender \& Society, 1, 2, 125-151.

West, C. and Zimmerman, D. H. (2009). Accounting for doing gender. Gender \& Society, 23, $1,112-122$.

Whitehead, S. (2014). Masculinities in Management: Hidden, Invisible, and Persistent. In Kumra, S., Simpson, R., \& Burke, R. J. (eds) The Oxford Handbook of Gender in Organisations. Oxford: Oxford University Press, 438-459.

Willig, C. (2013). Introducing Qualitative Research in Psychology. UK: McGraw-Hill Education.

Özbilgin, M. F., Beauregard, T. A., Tatli, A. and Bell, M. P. (2011). Work-life, diversity and intersectionality: A critical review and research agenda. International Journal of Management Reviews, 13, 2, 177-198. 
